\title{
Inter-Sectoral Linkage and External Trade Analysis for Virtual Water and Embodied Carbon Emissions in China
}

\author{
Huiping Huang ${ }^{1,2, *} \mathbb{D}$, Xinsheng $\mathrm{Li}^{3}$, Lianhai Cao ${ }^{1}$, Dongdong Jia ${ }^{3}{ }^{\mathbb{D}}$, Junlong Zhang ${ }^{4}$,
} Chunying Wang ${ }^{3}$ and Yuping Han ${ }^{3,5, *}$

1 College of Surveying and Geo-Informatics, North China University of Water Resources and Electric Power, Zhengzhou 450045, China; caolianhai1970@163.com

2 Collaborative Innovation Center of Water Resources Efficient Utilization and Support Engineering, Zhengzhou 450046, China

3 School of Conservancy, North China University of Water Resources and Electric Power, Zhengzhou 450045, China; lixinshenghs@163.com (X.L.); dongdongiia6@163.com (D.J.); wangchunying1987@yahoo.com (C.W.)

4 College of Geography and Environment, Shandong Normal University, Jinan 250358, China; Junlongzhangcq@hotmail.com

5 Henan Key Laboratory of Water Environment Simulation and Treatment, Zhengzhou 450046, China

* Correspondence: 13526882916@163.com (H.H.); han0118@163.com (Y.H.); Tel.: +86-135-2688-2916 (H.H.); +86-136-5380-9350 (Y.H.)

Received: 10 September 2018; Accepted: 10 November 2018; Published: 15 November 2018

check for updates

\begin{abstract}
In the globalized world, water utilization and carbon emissions are two important indicators for water and energy resources evaluation. This paper investigates the inter-sectoral linkage and external trade of virtual water (water embodied in products) and embodied carbon emissions in China based on input-output tables during 1997-2015. Results indicate that: inside China, agriculture, the electric and water industry are major virtual water suppliers, while heavy industrial sectors including the metal products industry, the petrochemical industry, other nonmetallic mineral products industry, and the mining industry are major embodied carbon emissions suppliers. China is the net exporter of virtual water $\left(137.15 \times 10^{9} \mathrm{~m}^{3}\right)$ and embodied carbon emissions $\left(16.05 \times 10^{8} \mathrm{t}\right)$. From the perspective of industrial chain, about $81 \%$ of virtual water export come from agriculture, the electric and water industry ultimately, and about $85 \%$ of embodied carbon emissions export come from the mining industry, the petrochemical industry, other nonmetallic mineral products industry, the metal products industry, and the electric and water industry ultimately.
\end{abstract}

Keywords: virtual water; embodied carbon emissions; input-output table; water use efficiency; carbon emissions intensity

\section{Introduction}

Problems of resource depletion and global warming caused by natural resource over exploitation and environmental deterioration have aroused global concern in recent years [1]. Among the problems, water scarcity and greenhouse gas (GHG) emissions are global challenges and severe threats to the sustainability of social development. It shows that 43 countries and 700 million people suffer water shortage problems [2]; accordingly, the water crisis has become a global environmental issue in the 21st century. Besides, GHG, especially carbon dioxide $\left(\mathrm{CO}_{2}\right)$ emissions, are considered to be the main causes of the global warming [3]. Trade in both goods and services have a rapid growth as globalization of the world economy since the 1980s. Globalization is increasing the separation of production and consumption locations of goods and services, and the effect of trade on water resources shortage and carbon emissions in different areas should to be taken into account [4]. 
Water embodied in products is defined as "virtual water" [5]. According to trade theory, regions or countries can import goods or services from the regions specialized in the production. Therefore, imports of water-intensive commodities from water-abundant to water-scarce areas can solve the water resources shortage. Zeitoun et al. [6] estimated that through crop and livestock trade during 1998-2014, annual net imports of virtual water in Nile Basin states occupied one third of the Nile River and were considered to play a key role in filling the freshwater deficits of the region. However, various studies have shown that the existing trade in virtual water is not consistent with the trade theory. Severely water-scarce developing countries such as Tunisia, Egypt, and India exported large amounts of virtual water embodied in crops and aggravated the regional water stress [7-9]. Meanwhile, some developed countries or regions such as Spain, European Union (EU) are net importers of virtual water $[10,11]$.

To produce near-zero net pollutant emissions, nearly 200 countries adopted The Paris Agreement of 2015 and determined the shared emissions reduction targets in the second half of this century [12]. However, countries with GHG emissions reduction tasks may fulfill their emissions reduction targets by increasing commodity imports from countries with non-emission reduction obligations [13-15]. Andrew et al. [16] reported the dependence on either exports or imports of carbon emissions for most major economies is rising. Additionally, several studies depicted the transfer of carbon emissions from developed to developing countries, and attempted to put forward some alternative solutions to reduce carbon emissions transfer. Zhong et al. [12] analyzed global embodied emissions trade for 39 countries from 1995 to 2011, and explored the determinants of the trade change from a spatial perspective. Antimiani et al. [17] developed a modified version of the computable general equilibrium model to evaluate the effect of alternative trade policy on carbon emissions. Furthermore, Eichner and Pethig [18], and Böhringer et al. [19] investigated the performance of a consumption-based carbon tax in the carbon emission trade.

In China, resource consumption, energy consumption, and the resulting carbon emissions have all risen sharply with the rapid development of the economy in recent years. China is one of the most water scarce countries, in which available water resource per capita is less than one quarter of the global average. Furthermore, the distribution and demand of water resources in China is uneven. Chen et al. [20] pointed out that there is only $19 \%$ of water resources but $64.15 \%$ cultivated land in north of the Yangtze River Basin in China. In addition, China's economic growth pattern is characterized by being significantly outwardly-oriented and has been recognized as the world factory. Since China joined the World Trade Organization (WTO) in 2001, great amounts of virtual water have been imported and exported, accompanied by massive commodities trade [21-23]. Not only large amounts of virtual water, but also massive embodied carbon emissions, are exported outside accompanied by the output of products. Yan and Yang [24] estimated that about 10-27\% of China's annual carbon emissions are produced inside China and consumed by foreign consumers from 1997 to 2007. Andersson [25] found that the embodied carbon emissions exported by China to developed countries increased rapidly from 1995 to 2008. Moreover, Yuan and Zhao [26] employed an input-output method combined with a sensitivity analysis to explore the impact of technological changes on embodied carbon emissions in high energy-consuming industries.

The transfer of virtual water and carbon emissions takes place not only among different regions but also among different sectors within one region. Determining the role of each sector in the supply chain of water consumption and carbon emissions can provide clarity for the task of water conservation and carbon emissions reduction. In order to grasp the correlation of water consumption and carbon emissions among different sectors, the internal linkage analysis should be considered. Duarte et al. [27] adopted a vertically integrated sectors approach to disaggregate pollution into its most significant components. Wen and Wang [28] developed an inter-sector linkage analyses based on a multi-regional input-output model to identify key sectors and provinces on the issue of carbon emissions in China. Fang and Chen $[29,30]$ detected the water and energy consumption coactions among different economic sectors in Bejing city, China, and characterized the role of each sector along the entire supply chain. Furthermore, Yang et al. [31] investigated the energy-water-carbon nexus from a sectoral perspective by utilizing an environmental input-output table. 
Currently, research conducted on water-carbon internal linkage among different sectors and on water-carbon trade mainly focuses on specific productions, economic effects and the corresponding measures separately, while the exploration on combining external trade with internal circulation, further tracking back to the ultimate source of virtual water and embodied carbon emissions exports from the perspective of supply chain have not been identified. Therefore, the specific objectives of this study are: (1) to explore the production structure and detect the inter-sectoral flow among different sectors of water and energy resources using inter-sectoral linkage analysis; (2) to illustrate the import and export of virtual water and embodied carbon emissions in international trade; (3) to identify ultimate sources of virtual water and carbon emissions and depict key sectors in the whole economic system.

\section{Materials and Methods}

\subsection{Data}

Water consumption data of agriculture and industry were obtained from the China Water Resources Bulletin, which is released by the Ministry of Water Resources of the People's Republic of China. Water consumption data of architecture and service industry was obtained from the Statistical Yearbook and Economic Yearbook. Standard coal quantity consumed by every sector was obtained from the China Energy Statistics Yearbook. Energy consumption was multiplied by standard coal consumed by every sector and carbon emission coefficient per ton of standard coal (a value of 0.7559 recommended by the IPCC). Input-output tables of eight years from 1997 to 2015 (1997, 2000, 2002, $2005,2007,2010,2012$, and 2015) were obtained from the China Statistical Yearbook. In order to cover all sectors in the Statistics Yearbook and Environmental Yearbook and ensure the reliability of the results, this paper merged sectors in the input-output tables into 14 sectors. The merging method and result is exhibited in Table 1.

Table 1. Sectors aggregation.

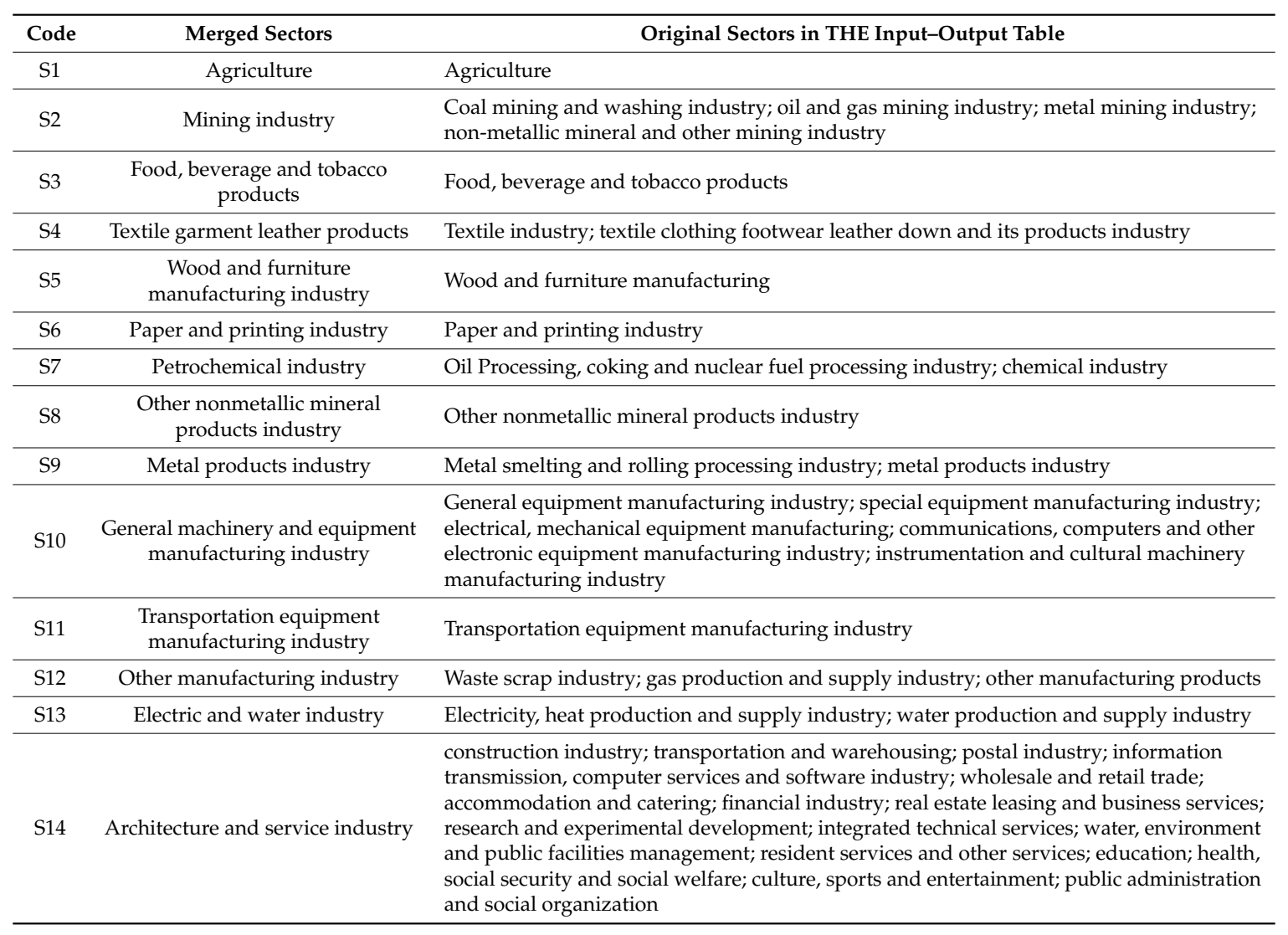




\subsection{Methodologies}

\subsubsection{Input-Output Analysis}

Input-output table describes the flow of goods and services from producing sectors to consuming sectors. The input-output analysis based on the input-output table can depict virtual water and embodied carbon emissions flow within an economic system. The equation of the input-output model structure can be described as [32]:

$$
\sum_{j=1}^{n} x_{i j}+y_{i}=x_{i} \quad(i=1,2,3 \ldots n)
$$

where $x_{i j}$ is the intermediate input of sector $i$ to sector $j, y_{i}$ is the total output of sector $i ; x_{i}$ represents the final demand of sector $i$, and $n$ is sector number.

The direct consumption coefficient $a_{i j}$ indicates the direct input from sector $i$ needed to increase output per monetary unit in sector $j . a_{i j}$ can be calculated by the following equation:

$$
a_{i j}=x_{i j} / x_{j}
$$

And the Equation (1) can be rearranged as:

$$
\sum_{j=1}^{n} a_{i j} x_{j}+y_{i}=x_{i}
$$

In matrix notation and for the economy as a whole, this becomes:

$$
X=A X+Y=(I-A)^{-1} Y=B Y=\left[b_{i j}\right] Y
$$

where $X$ is the total output matrix, $A$ is the direct consumption coefficient matrix, $(I-A)^{-1}$ and $B$ are both Leontief inverse matrices, $B$ is also called as total consumption coefficient matrix, $Y$ means final demand matrix and $b_{i j}$ denotes the whole (indirect and direct) demand of the output of sector $i$ for unit final products of sector $j$.

\subsubsection{Environmental Input-Output Analysis}

When the water (energy) consumption of every sector is added into a monetary input-output table, the environmental input-output table is constructed [33]. The table structure is shown in Table 2.

Table 2. Environmental input-output table.

\begin{tabular}{cccccccccc}
\hline Input/Output & & \multicolumn{3}{c}{ Intermediate Use } & \multicolumn{2}{c}{ Total Use } & Import $\begin{array}{c}\text { Gross } \\
\text { Output }\end{array}$ \\
\hline & & $\mathbf{1}$ & $\mathbf{2}$ & $\ldots$ & $\boldsymbol{n}$ & Expert & Sum & \\
\hline Intermediate use & 1 & $X_{11}$ & $X_{12}$ & $\ldots$ & $X_{1 n}$ & $E X_{1}$ & $Y_{1}$ & $I M_{1}$ & $X_{1}$ \\
& 2 & $X_{21}$ & $X_{22}$ & $\ldots$ & $X_{2 n}$ & $E X_{2}$ & $Y_{2}$ & $I M_{2}$ & $X_{2}$ \\
Gross input & $\ldots$ & $\ldots$ & $\ldots$ & $\ldots$ & $\ldots$ & $\ldots$ & $\ldots$ & $\ldots$ & $\ldots$ \\
Water & $n$ & $X_{n 1}$ & $X_{n 2}$ & $\ldots$ & $X_{n n}$ & $E X_{n}$ & $Y_{n}$ & $I M_{n}$ & $X_{n}$ \\
(energy)consumption & & $X_{1}$ & $X_{2}$ & $\ldots$ & $X_{n}$ & & & & \\
\hline
\end{tabular}

Note. $E X_{j}$ is the export of sector $j, I M_{j}$ is the import of sector $j$, and $W_{d n}$ is the direct water (carbon) consumption by the $n$th sector.

In accordance with the definition of the direct consumption coefficient $a_{i j}$, the direct water (energy) consumption coefficient is defined as:

$$
q_{j}=W_{j} / X_{j}
$$


where $q_{j}$ is the amount of water (energy) consumed directly by the sector $j$.

The Equation (5) can be rewritten as:

$$
W_{j}=q_{j} X_{j}=q_{j}(I-A)^{-1} Y=\left[\delta_{i j}\right] Y
$$

where $\left[\delta_{i j}\right]$ is the total (energy) consumption coefficient matrix.

\subsubsection{Inter-Sectoral Linkage Analysis of Virtual Water and Embodied Carbon Emissions}

Inter-sectoral linkage analysis, derived from input-output analysis, can distinguish the direct and indirect consumption of resources as well as the role of each sector in the economic system [34]. This method has been modified as the Hypothesis Extraction Method, which assumes that $B_{s}$ is an industrial group consisting of one or several sectors in the economic system, $B_{-s}$ is an industrial group of the remaining sectors, and the economic system can be described as:

$$
\left(\begin{array}{c}
x_{s} \\
x_{-s}
\end{array}\right)=\left(\begin{array}{c}
A_{s, s} A_{s,-s} \\
A_{-s, s} A_{-s,-s}
\end{array}\right)\left(\begin{array}{c}
x_{s} \\
x_{-s}
\end{array}\right)+\left(\begin{array}{c}
y_{s} \\
y_{-s}
\end{array}\right)=\left(\begin{array}{c}
\Delta_{s, s} \Delta_{s,-s} \\
\Delta_{-s, s} \Delta_{-s,-s}
\end{array}\right)\left(\begin{array}{c}
y_{s} \\
y_{-s}
\end{array}\right)
$$

where $X=\left(\begin{array}{c}x_{s} \\ x_{-s}\end{array}\right)$ is the total output vectors, $A=\left(\begin{array}{c}A_{s, s} A_{s,-s} \\ A_{-s, s} A_{-s,-s}\end{array}\right)$ is the direct consumption coefficient matrix, $(I-A)^{-1}=\left(\begin{array}{c}\Delta_{s, s} \Delta_{s,-s} \\ \Delta_{-s, s} \Delta_{-s,-s}\end{array}\right)$ is the inverse matrix of $\mathrm{A}$, and $Y=\left(\begin{array}{c}y_{s} \\ y_{-s}\end{array}\right)$ is the final demand vector.

Linkage analysis includes four elements ([30]): the internal effect (IE), mixed effect $(M E)$, net backward linkage (NBL), and net forward linkage (NFL). These parameters can be expressed as:

$$
\begin{aligned}
& I E=q_{s}(I-A)^{-1} y_{s} \\
& M E=q_{s}\left(\Delta_{s, s}-(I-A)^{-1}\right) y_{s} \\
& N B L=q_{-s} \Delta_{-s, s} y_{s} \\
& N F L=q_{s} \Delta_{s,-s} y_{-s}
\end{aligned}
$$

The relationship of the parameters listed above is described in Figure 1.

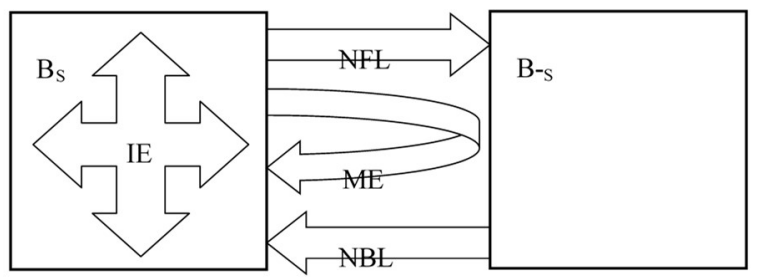

Figure 1. The relationship of different parameters.

As shown in Figure 1, regional economic systems are divided into sector groups $B_{s}$ and $B_{-s}$. IE is the water resources consumed or carbon emissions caused by sector $B_{S}$ when the production and transaction of $B_{s}$ products are completed without connection with $B_{-s} . M E$ concerns the water resources consumed or carbon emissions caused which are purchased by $B_{-s}$ from $B_{s}$ as the intermediate input products; then these products return to $B_{S}$ via trade. NFL is the net exported water resources or carbon emissions of $B_{s}$ to $B_{-s}$. NBL considers the net import of water resources or carbon emissions of $B_{s}$ from $B_{-s}$ as the final demand.

Direct consumption $(D C)$ refers to the direct utilization of resources to meet the final demand of one sector. The vertically integrated consumption $(V I C)$ is the total consumption of resources to 
fulfill the final demand of one sector, including domestic consumption and the resource imports from outside.

The correlations of the above listed elements are as:

$$
\begin{aligned}
& D C=I E+M E+N F L \\
& V I C=I E+M E+N B L
\end{aligned}
$$

If $D C<$ VIC for one sector, it indicates that this sector obtains resources or emissions from other sectors, or this sector provides resources or emissions for other sectors.

Introduce $N T$ to represent the input and output of the resources and emissions of sectors. If $N T$ is less than 0 , it indicates that $B_{s}$ obtains resources and carbon emissions from $B_{-s}$, and conversely $B_{S}$ export resources and carbon emissions to $B_{-s}$.

$$
N T=N F L-N B L
$$

\subsubsection{Virtual Water or Carbon Emissions Trade between China and Other Regions}

According to the description of linkage analysis, commodity production of one sector will obtain water (energy) resources from other sectors. $N F L_{i j}$ represents the virtual water or carbon emissions transferred from sector $i$ to sector $j$. Therefore, the virtual water or carbon emissions exported can be calculated in two methods: one is virtual water or carbon emissions export not considering the internal linkage of different sectors $\left(W_{n e t}\right)$; the other is virtual water or carbon emissions export considering the internal linkage of different sectors $\left(W_{\text {linkage }}\right)$.

Virtual water or embodied carbon emissions not considering the internal linkage of different sectors can be calculated by multiplying the total consumption coefficient matrix by the export of import matrix. The formula of the trade can be expressed [35]:

$$
W_{\text {net } j}=W_{E j}-W_{M j}=q_{j} E_{j}-q_{j} M_{j}
$$

where $W_{E j}$ is water or carbon emissions export of sector $j, W_{M j}$ is virtual water or carbon emissions import of sector $j, W_{\text {netj }}$ is net export of virtual water or carbon emissions of sector $j$, and $E_{j}$ and $M_{j}$ are output and input values in the column vectors of input-output table.

$$
W_{\text {linkage } i}=\sum_{i=1}^{n} \frac{N F L_{i \rightarrow j}}{\sum_{j=1}^{n} N F L_{i \rightarrow j}} W_{\text {net } i}
$$

Equations (11) and (12) suppose that the total consumption coefficients of imported and exported products are the same, and it is obviously different from the actual situation. However, it is reasonable if the environmental impact of the import can be considered as saving the country's resource consumption and reducing its carbon emissions.

\section{Results}

\subsection{Linkage Analysis}

\subsubsection{Linkage Analysis of Water Consumption}

In the whole economic system, the VIC of water resources is combined with the final demand of sectors (same as DC). The average water consumption during $1997-2015$ is $553.21 \times 10^{9} \mathrm{~m}^{3}$ in China. Figure 2 shows the $D C$ of $S 1$ is $375.87 \times 10^{9} \mathrm{~m}^{3}$, which accounts for $67.9 \%$ of annual water consumption. However, the VIC is 0.39 times of DC, which indicates that about $60 \%$ of the water consumption of S1 is transferred to other sectors. The DC of S13 is $79.15 \times 10^{9} \mathrm{~m}^{3}$, shows that $14.3 \%$ water is transferred to other sectors. Sectors transferring water to other sectors also include S6, S7, S8 and S9. 
The IE of $\mathrm{S} 1$ is $132.12 \times 10^{9} \mathrm{~m}^{3}$, accounting for $91.0 \%$ of VIC, which describes that $91.0 \%$ of the water resources that consumed by S1 come from the internal exchange of products. The NFL of S1 is $220.71 \times 10^{9} \mathrm{~m}^{3}$, accounting for $58.72 \%$ of $D C$, while the ratios of $I E$, and $M E$ to $D C$ are $35.1 \%$ and $2.3 \%$. It indicates that large amounts of water are transferred to other sectors; therefore, whether the demand of water resources in other sectors can be satisfied depends largely on the virtual water output of S1. The NBL of S1 is $5.73 \times 10^{9} \mathrm{~m}^{3}$ which represents $3.95 \%$ of VIC; The NT of S1 is $220.71 \times 10^{9} \mathrm{~m}^{3}$. The data above illustrate that $\mathrm{S} 1$ exports large amounts of water to other sectors but imports little from outside and has high independence. The water consumption characteristic of S13 is similar to S1.

The ratios of IE to VIC of S6, S7, S8, S9 and S2 are $0.28,0.16,0.15,0.23$ and 0.12 , respectively, which describes that $28 \%, 16 \%, 15 \%, 23 \%$ and $12 \%$ of the water resources that these sectors consume come from the product internal exchange. The ratios of NFL to NBL of S6, S7, S8, S9 and S2 are 1.16, 1.91, $1.96,2.05$ and 1.38 , respectively, which demonstrates that although these five sectors totally exported water, they also imported a great deal of water from other sectors.

VIC is larger than DC for S3, S4, S5, S10, S11, S12 and S14, which indicates that these seven sectors need to obtain water from other sectors; the import percent is more than $90 \%$ for S3, S4, S5, S10, S11, and $\mathrm{S} 12$.

$D C$ of $\mathrm{S} 14$ is $47.49 \times 10^{9} \mathrm{~m}^{3}$ which makes up $8.58 \%$ of the annual water consumption in China. NBL of S14 is $137.53 \times 10^{9} \mathrm{~m}^{3}$, amounting to $78.0 \%$ of VIC which indicates that $78.0 \%$ of the water resources consumed by S14 are obtained from other sectors. $M E$ of S14 is ranks the second among the 14 sectors, accounting for $10.04 \%$ and, $2.03 \%$ of DC and VIC. It demonstrates that large amounts of virtual water embodied in products are sold to other sectors as intermediate processing, and then S14 repurchases products from other sectors which lead to the return of virtual water.

Overall, NT of S3, S4, S5, S10, S11, S12 and S14 are less than 0, which indicates that these sectors obtain water resources from other sectors. NT of all of other sectors are greater than 0 .
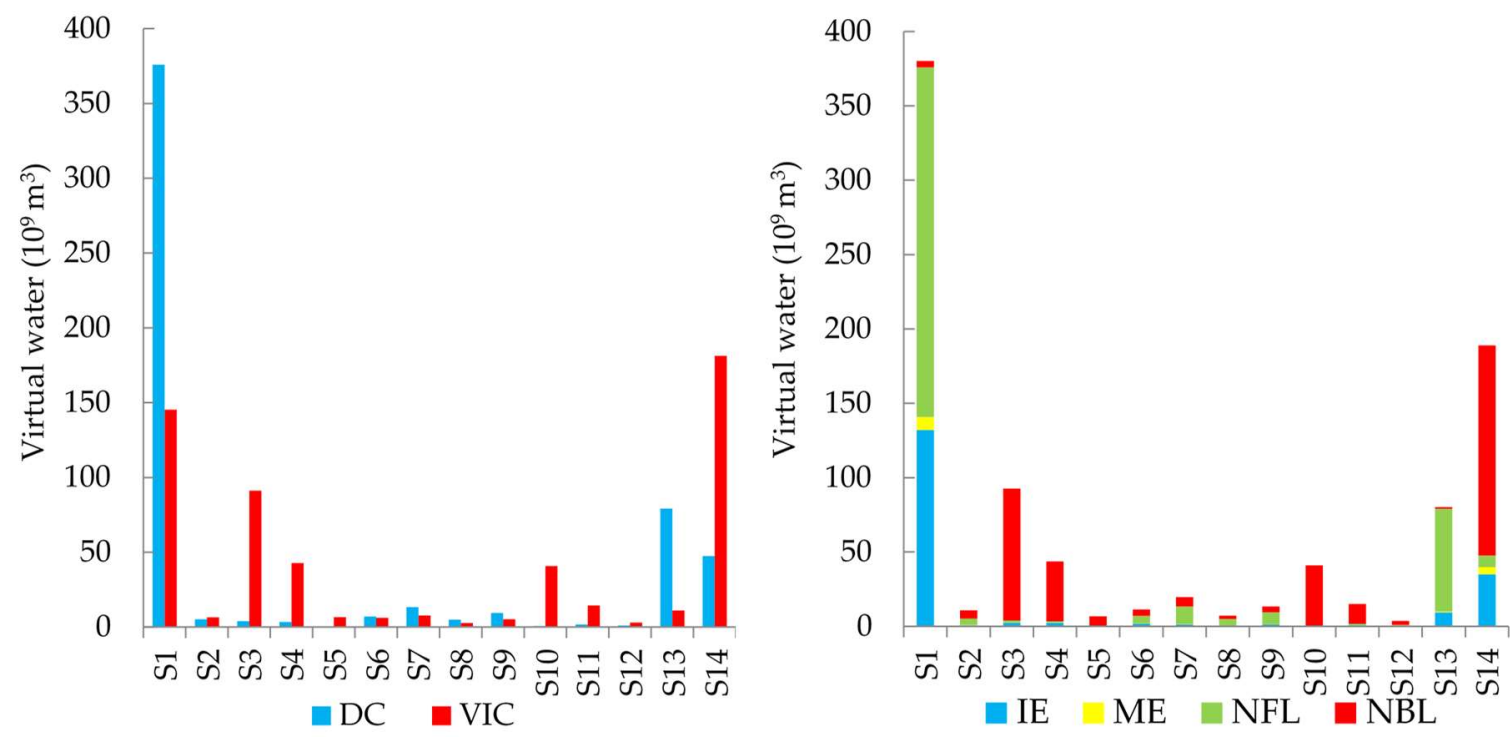

Figure 2. Virtual water flows among different sectors in China.

\subsubsection{Linkage Analysis of Carbon Emissions}

Figure 3 shows the internal linkage of different sectors for carbon emissions in China during 1997-2015. It can be seen that DC is larger than VIC in S2, S7, S8, S9, S12 and S13, and it indicates that these sectors output carbon emissions to other sectors. DC is smaller than VIC in S3, S4, S5, S10, S11, and S14 which indicates that these sectors import carbon emissions from other sectors. There is little difference between DC and VIC in S1 and S6.

The carbon emissions characteristics of S2, S7, S8, S9, S12 and S13 are similar. The ratios of IE to VIC of these six sectors are about 0.5 , which indicates that approximately $50 \%$ of the energy these 
sectors consumed comes from the internal exchange of products. The ratio of NFL to DC is about 0.9, which illustrates that about $90 \%$ of the energy consumption of these sectors is transferred into other sectors. NFL is more than 10 times NBL in S7, S8, S9 and S13 sectors, about five times NBL in S2 and $\mathrm{S} 12$, which illustrates that these sectors output more energy than that they obtain from other sectors.

IE of S3, S4, and S5 account for more than $50 \%$ of DC and are less than $30 \%$ of VIC, which indicates that the energy consumption of these sectors has not only certain independence but also certain dependence on other sectors. The NBL of S10, S11, and S14 are 9.44, 5.39 and 2.22 times DC, and $93.83 \%, 89.47 \%$, and $73.19 \%$ of VIC, which describes that these sectors largely rely on energy from other sectors to meet their final demand. The IE and ME of S14 are the largest of all sectors, which shows that S14 has a noticeable reliance on internal energy circulation, and it has the largest amount of embodied carbon emissions exchange with other sectors to satisfy its own final demand.

The DC of S1 and S6 is almost the same as their VIC, and NBL are 0.72 and 0.62 times DC which account for $68.36 \%$ and $72.42 \%$ of their VIC. NFL of S1 and S6 are $0.68,0.72$ times their VIC. This indicates that these two sectors not only export a certain amount of energy to other sectors but also import nearly the same amount of energy from outside to meet their final demands.

The NT of S2, S6, S7, S8, S9, S12 and S13 are less than 0 , which indicates that these sectors obtain carbon emissions from other sectors inside China. The NT of the other sectors are greater than 0 .
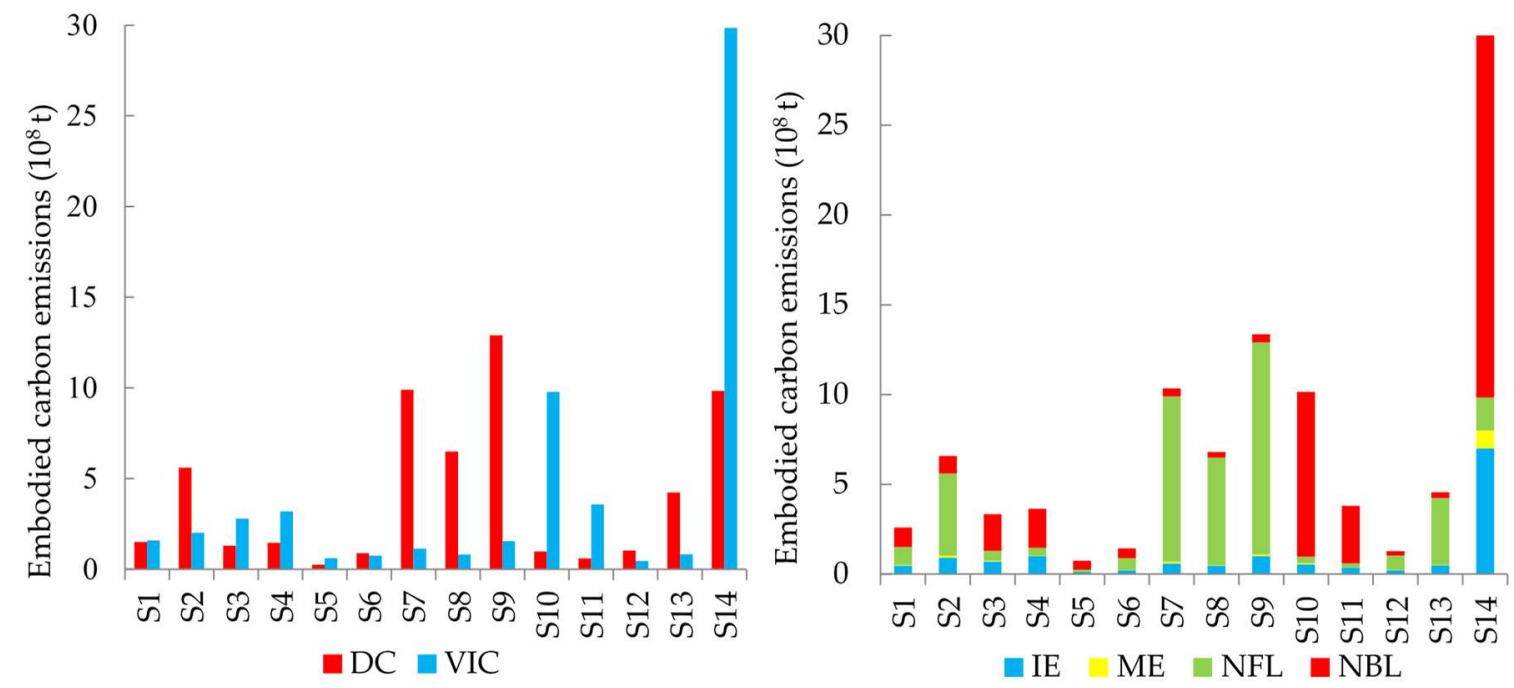

Figure 3. Carbon emissions flows among different sectors in China.

\subsection{Trade between China and Other Regions}

\subsubsection{Virtual Water Trade}

(1) The variation of China's virtual water import and export

Since China joined the WTO in 2001, there has been substantial growth in both its export and import. The virtual water trade (not considering internal linkage) is illustrated in Figure 4. During 1997-2015, the export and import quota increased from $182.7 \times 10^{9}$ and $142.36 \times 10^{9}$ dollars to $2342.3 \times 10^{9}$ and $2298.02 \times 10^{9}$ dollars, representing an enhancement of 12.82 and 16.14 times, respectively. Due to the rapid increase of China's international trade, virtual water export peaked at $156.08 \times 10^{9} \mathrm{~m}^{3}$ in 2007, up from $83.22 \times 10^{9} \mathrm{~m}^{3}$ in 1997, representing an increase of $87.55 \%$; virtual water import peaked at $131.26 \times 10^{9} \mathrm{~m}^{3}$ in 2005 , up from $61.2 \times 10^{9} \mathrm{~m}^{3}$ in 1997 , representing an increase of $130.26 \%$ (Figure 4a). China was a net exporter of virtual water from 1997 to 2015, and the total amount of virtual water exported was $137.15 \times 10^{9} \mathrm{~m}^{3}$, which exacerbated its water scarcity. Fortunately, the net export of virtual water significantly declined after 2007. 
According to the virtual water trade calculation formula, the amount of virtual water import and export are determined by two factors: the trade volume and the total water consumption coefficients. The import, export and net export volume of commodities show a rapid rise during 1997-2015, while the direct water consumption coefficients decrease rapidly from $704.8 \mathrm{~m}^{3} / 10^{4} \mathrm{CNY}$ to $89.03 \mathrm{~m}^{3} / 10^{4}$ CNY (Figure 4b). Virtual water import, export and net export show a slow increase during 1997-2007 and a total decrease in 2007-2015, which is attributing to the enhancement of water utilization efficiency.

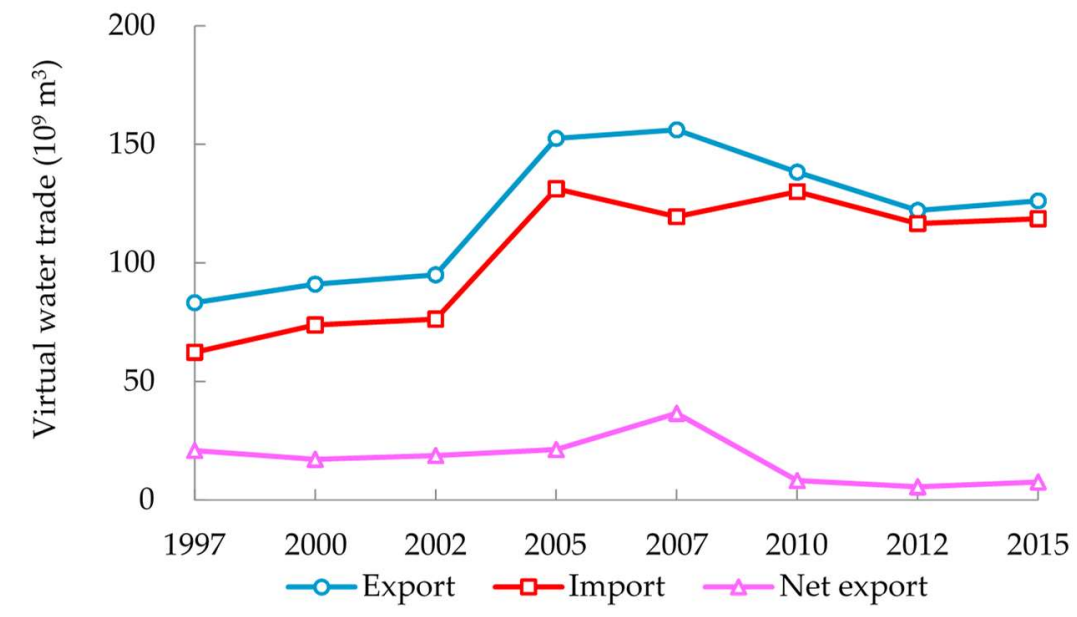

(a)

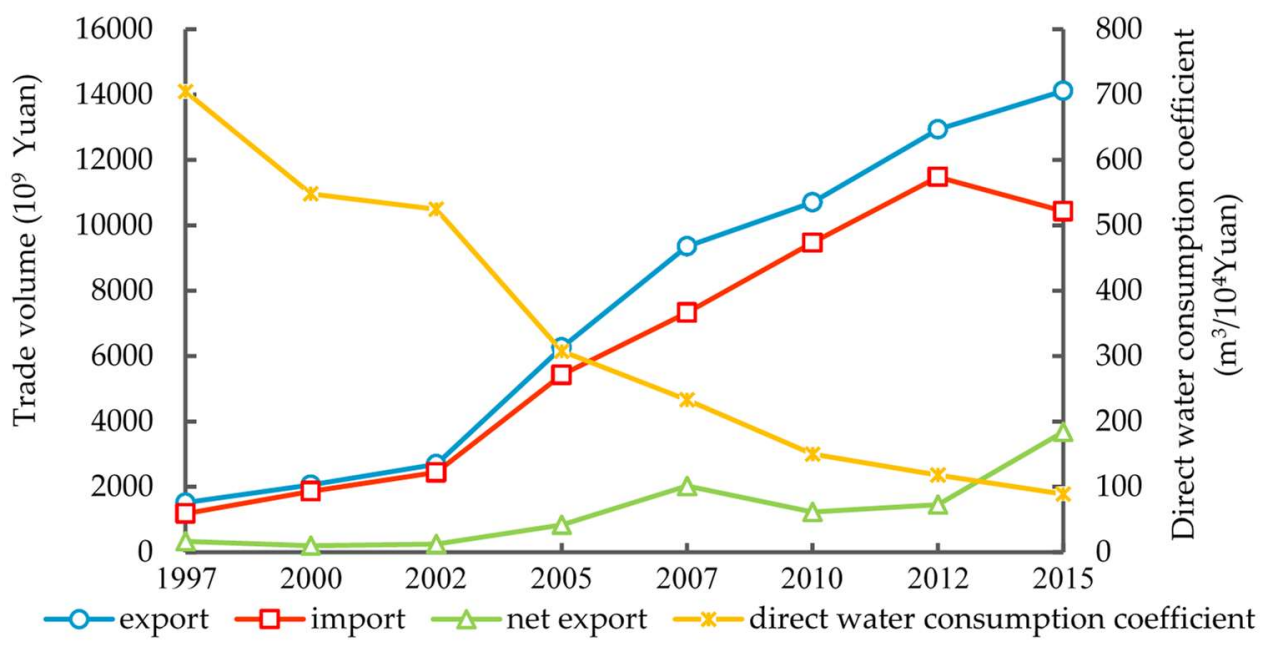

(b)

Figure 4. (a) Virtual water trade in China. (b) Trade volume and direct water consumption coefficient.

(2) Virtual water trade from perspective of sectors

As illustrated in Figure 5, S10, S4, S14, S7, and S3 are main virtual water export sectors in China. Figure 5 a shows that the average virtual water exported by the five sectors was $29.19 \times 10^{9} \mathrm{~m}^{3}, 27.66$ $\times 10^{9} \mathrm{~m}^{3}, 14.49 \times 10^{9} \mathrm{~m}^{3}, 11.03 \times 10^{9} \mathrm{~m}^{3}$ and $8.25 \times 10^{9} \mathrm{~m}^{3}$, respectively, and the export proportion sums up to $75.2 \%$ (Figure $5 b$ ). The export proportions sum of S4 and S10 amount to $47.2 \%$, which is almost half of the total export. Other than S14, the five sectors listed all belong to manufacturing industries, and it indicates that manufacturing industries are the major pulling force on virtual water exports in China. S1 plays an insignificant role in China's virtual water export. On the one hand, China's government emphasized the development of manufacturing sectors since the reform and open policy, and China has become the number one manufacturing country in the world; on the other hand, 
China has the largest population in the world and the limited cultivated land also restricts the export of agricultural products.

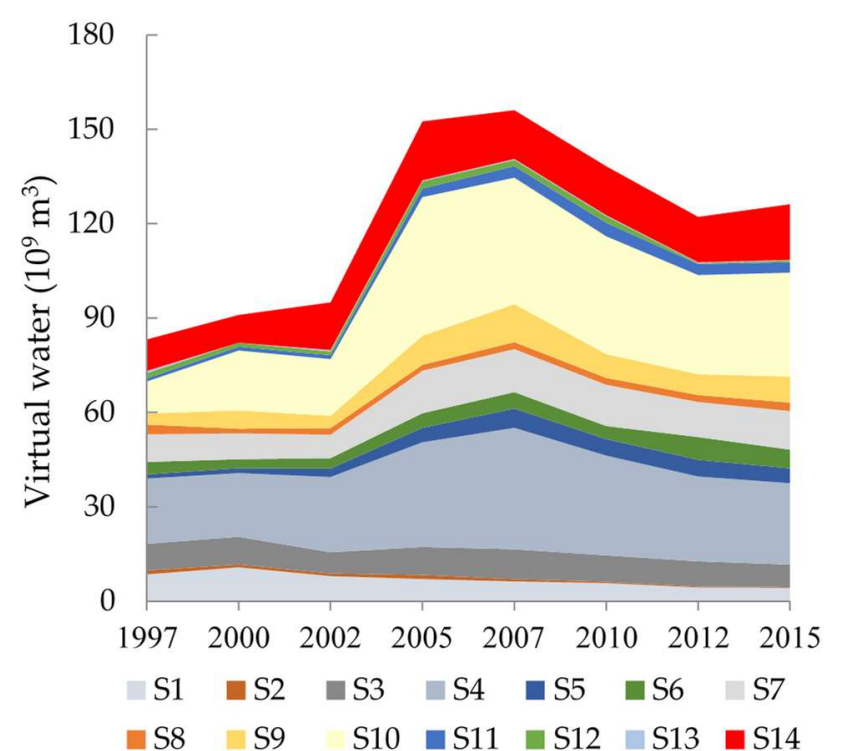

(a)

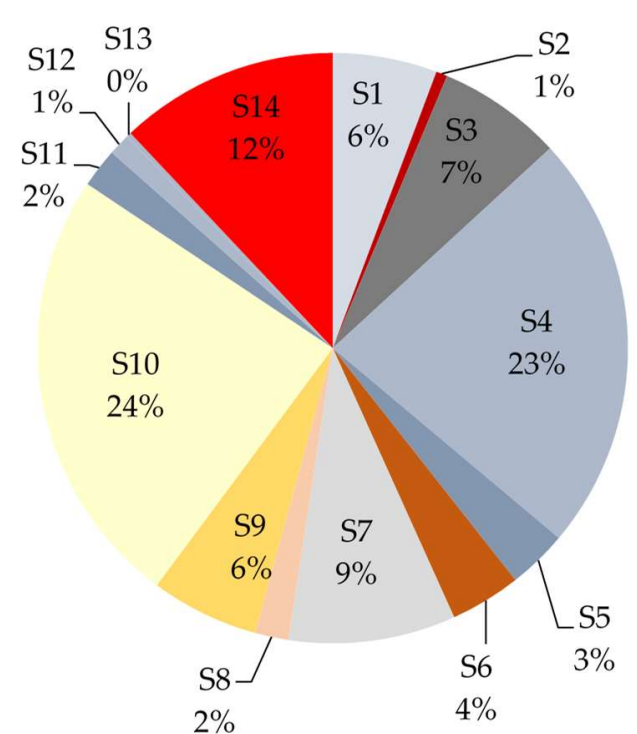

(b)

Figure 5. (a) Virtual water export of every sector. (b) Export proportion of every sector.

Figure 6 demonstrates the virtual water imported by every sector. The average volume of virtual water imported in S10, S1, S7 and S2 is $25.99 \times 10^{9} \mathrm{~m}^{3}, 19.16 \times 10^{9} \mathrm{~m}^{3}, 15.61 \times 10^{9} \mathrm{~m}^{3}$, and $8.77 \times 10^{9} \mathrm{~m}^{3}$ (Figure $6 \mathrm{a}$ ), and the total import of these four sectors represents $67.23 \%$ of the whole virtual water import in China during 1997-2015 (Figure 6b). Virtual water imports in S1 and S2 show significant increases, while import in S10 and S7 show a significantly declining trend. It can be analyzed that China has optimized its import structure, that is, the proportion of the primary products ascending and that of the industrial products declined. This indicates China has begun to attach importance to the protection of resource-intensive products and to strengthen its import.

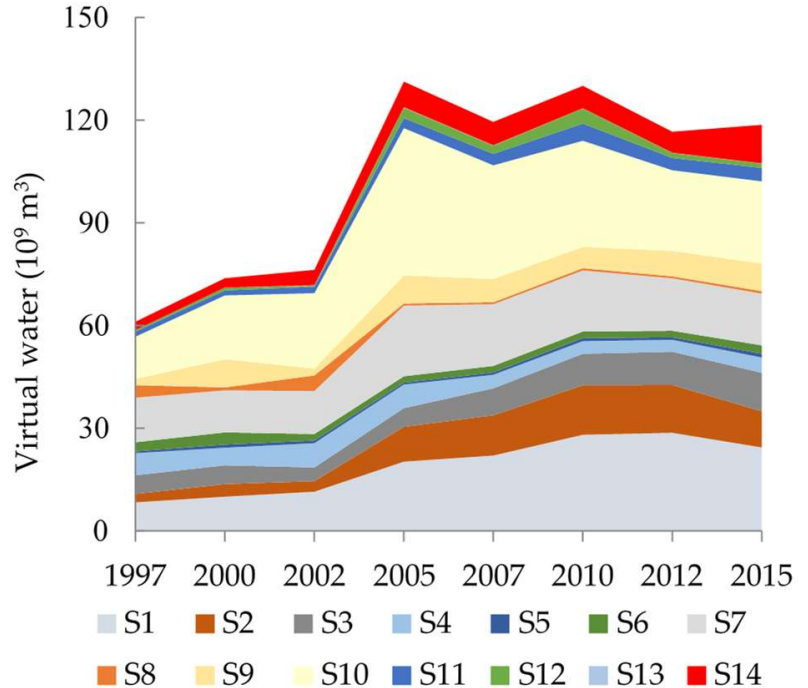

(a)

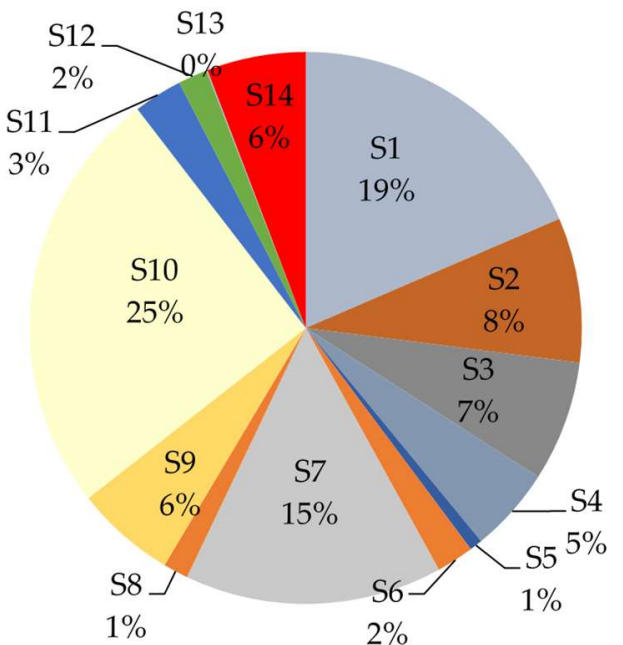

(b)

Figure 6. (a) Virtual water import of every sector. (b) Export proportion of every sector. 
Figure 7 shows that S1, S2, S7, S11, and S12 are net importing sectors of virtual water; the import sum of S1, S2 and S7 is $20.30 \times 10^{9} \mathrm{~m}^{3}$, which accounts for $79.33 \%$ of the whole net import; S3, S4, S5, S6, S8, S9, S10, S13, and S14 are net exporters of virtual water; the export sum of S4 and S14 is $31.0 \times 10^{9} \mathrm{~m}^{3}$, which accounts for $72.55 \%$ of the whole net export. Overall, the main net import sectors are S1, S2, and S7, while the main net export sectors are S14, and especially S4, whose net export accounted for $52.68 \%$ of the whole net export of China. S1 is the most water-consuming sector in China at present; the net import of virtual water S1 has saved its water resources to some degree.

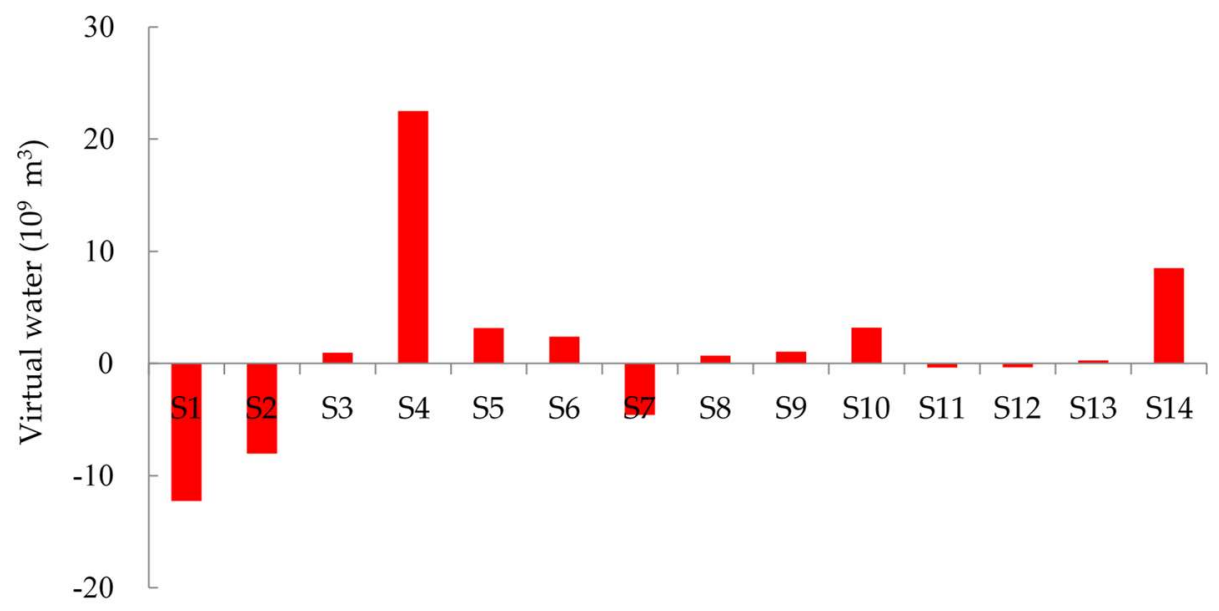

Figure 7. Net virtual water exports by every sector.

\subsubsection{Embodied Carbon Emissions Trade}

(1) The variation of China's carbon emissions import and export

Figure 8 shows that there is an abrupt increase of both carbon emissions import and export during the period of 2002-2005, and slight fluctuations after 2005. After 2002, both the export and import of embodied carbon emissions are greater than $20 \times 10^{8} \mathrm{t}$. The maximum and minimum net export occurred in 2007 and 2000, with the values $5.67 \times 10^{8} \mathrm{t}$ and $0.38 \times 10^{8} \mathrm{t}$. Overall, China is a typical net exporter of carbon emissions, and the average annual net export is $2.0 \times 10^{8} \mathrm{t}$ in the period of 1997-2015.

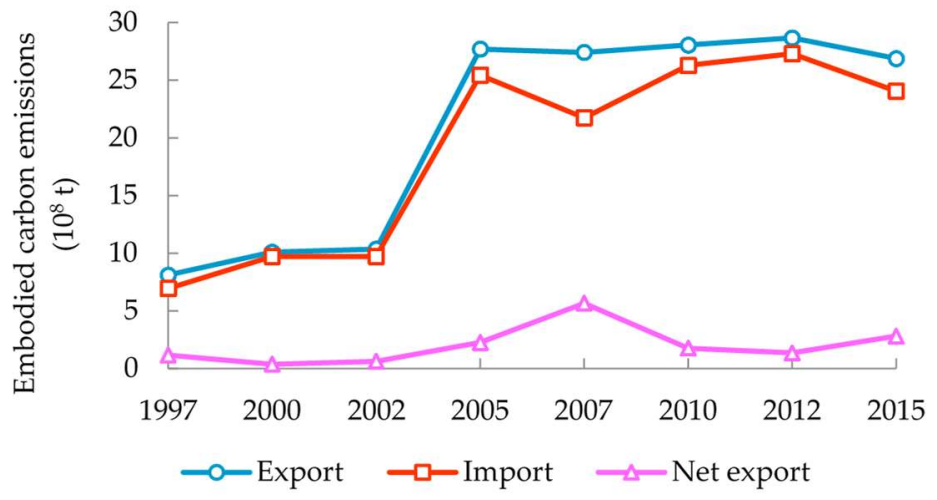

Figure 8. Embodied carbon emissions trade in China.

(2) Embodied carbon emissions trade from perspective of sectors

Figure 9 indicates that carbon emissions export mainly occurs in S10, S9, S14, S7, and S4 during 1997-2015. The average export of embodied carbon emissions of these five sectors is $7.83 \times 10^{8} \mathrm{t}$, $2.76 \times 10^{8} \mathrm{t}, 2.47 \times 10^{8} \mathrm{t}, 2.41 \times 10^{8} \mathrm{t}$ and $2.21 \times 10^{8} \mathrm{t}$ (Figure 9a) and the export proportion sums up to $85.0 \%$ (Figure $9 \mathrm{~b}$ ). S10 is the most important sector concerning carbon emissions, and the export 
volume increases rapidly from $1.62 \times 10^{8} \mathrm{t}$ in 1997 to $10.26 \times 10^{8} \mathrm{t}$ in 2015; the proportion export of S10 has been also rising. The export proportion of S9, S7 and S14 changes slightly though there are increases in export volumes of these three sectors. The export proportion of $\mathrm{S} 4$ shows a declining trend, and there are perhaps two reasons for it: one is the reduction of the total carbon emission intensity and the other is the decline of trade volume in S4. Exports of all sectors show sharp rises after 2002 and then keep relatively stable. The manufacturing industries are a major pulling force on the exports of embodied carbon emissions in China.

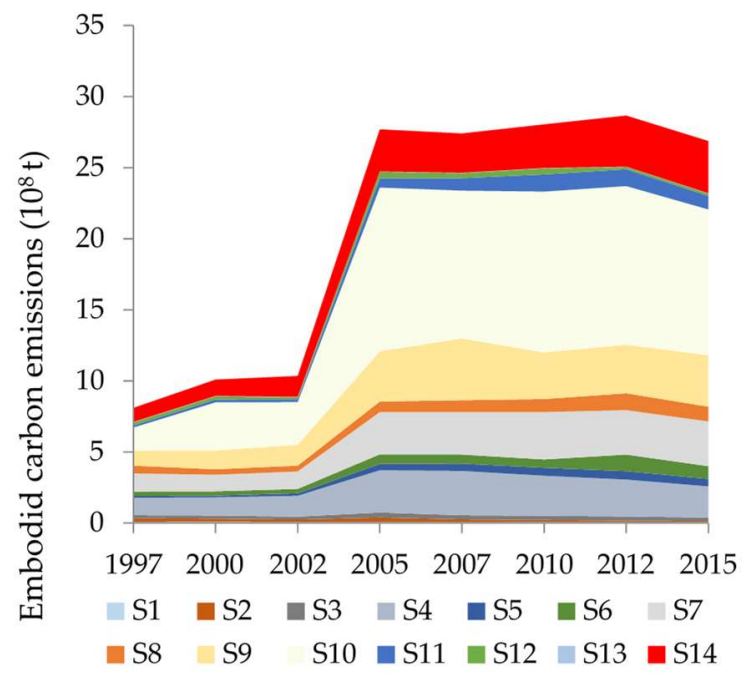

(a)

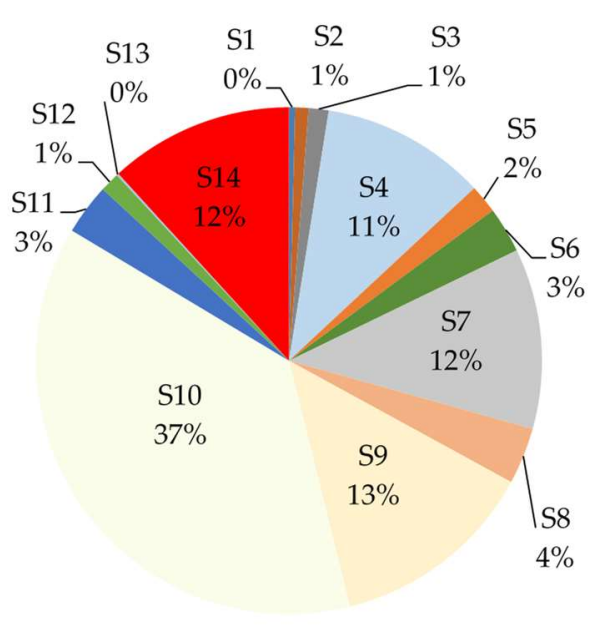

(b)

Figure 9. (a) Carbon emissions export of every sector. (b) Export proportion of every sector.

Embodied carbon emissions of all sectors show a significant increase during 1997-2005 and 2007-2012, while showing a decrease during the period of 2012-2015, and the annual average embodied carbon emissions imports of these four sectors reached $13.59 \times 10^{8} \mathrm{t}$ (Figure 10a). China imports more embodied carbon emissions in such sectors as S10, S7, S2 and S9, and the import proportions of the four sectors are $36 \%, 18 \%, 14 \%$ and $12 \%$, respectively (Figure $10 \mathrm{~b}$ ).

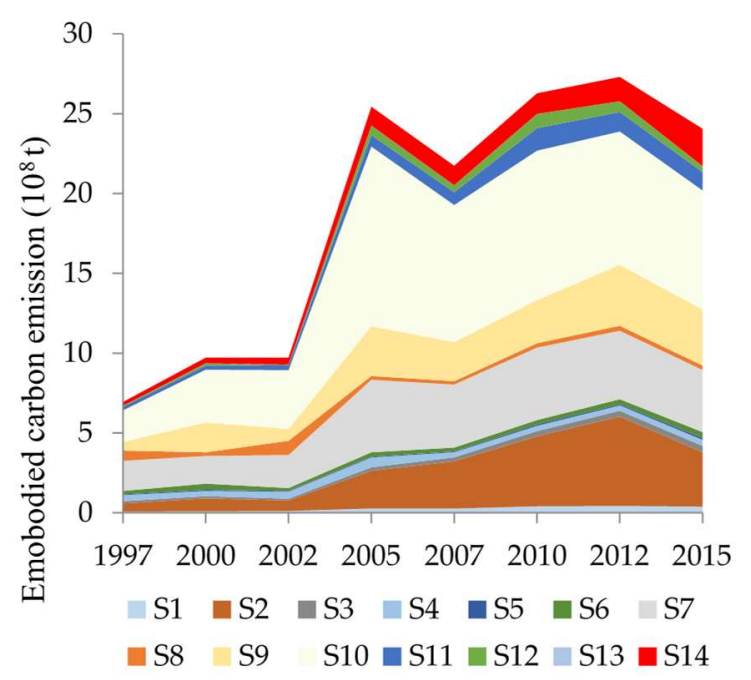

(a)

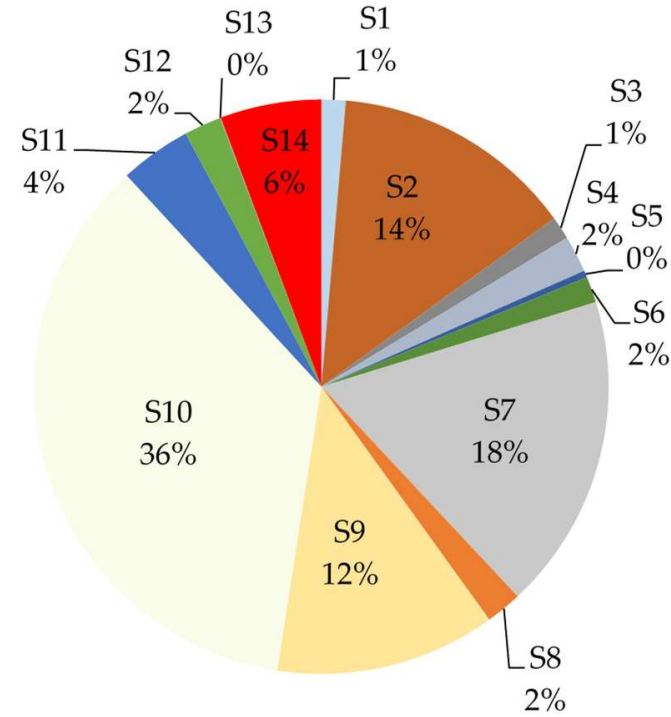

(b)

Figure 10. (a) Carbon emissions import of every sector. (b) Import proportion of every sector. 
Figure 11 shows that S1, S2, S7, S11 and S12 are net embodied carbon emissions import sectors. The annual average net exports of embodied carbon emissions in S4, S10 and S14 are all more than $1.0 \times 10^{8} \mathrm{t}$, while net imports of S2 and S7 are $2.41 \times 10^{8} \mathrm{t}$ and $0.96 \times 10^{8} \mathrm{t}$, respectively.

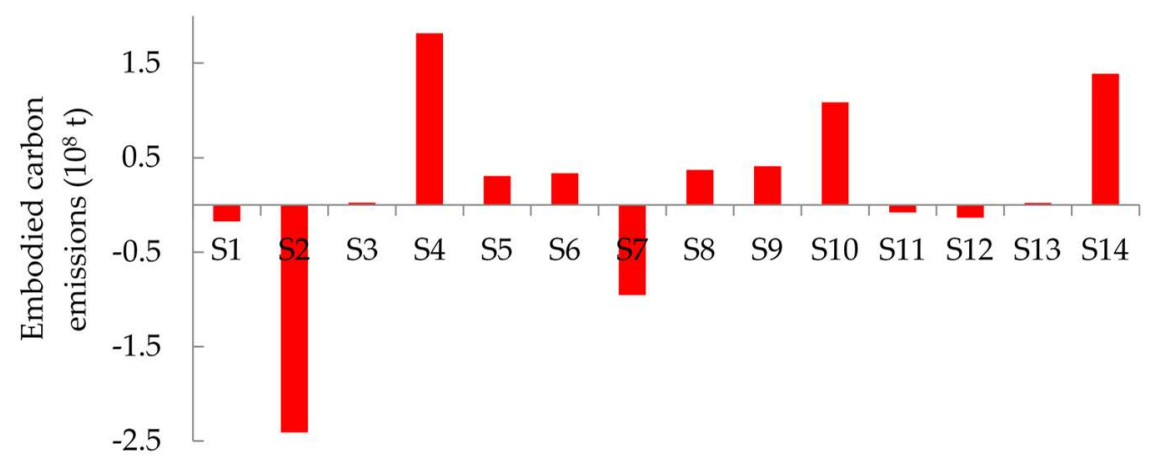

Figure 11. Net embodied carbon emissions exports by every sector.

S10, S7 and S9, which are manufacturing sectors, play important roles in both exports and imports in China's embodied carbon emissions trade. S2 and S7 dominate in the net imports, while S4, S10 and S14 dominate in net exports of China's embodied carbon emissions trade.

\section{Discussion}

\subsection{Virtual Water Flow Chains}

Overall, domestic virtual water flows among different sectors were much larger than trade between China and other regions except in S2. Table 3 demonstrates the inter-sectoral virtual water flow during 1997-2015; the row data represents the water that the row sector flows to the column sectors and the column data represent the water that the row sector acquires from the column sectors. It indicates that the products of S1 and S13 are major virtual water suppliers for other sectors. The annual average virtual water flowing from sector S1 to sectors S3, S14, S4 and S10 are $82.74 \times 10^{9} \mathrm{~m}^{3}, 73.71 \times 10^{9} \mathrm{~m}^{3}$, $32.1 \times 10^{9} \mathrm{~m}^{3}$ and $12.56 \times 10^{9} \mathrm{~m}^{3}$; there is little difference among the annual average water flowing from S13 to other sectors except to S14 and S10. S14, S3 and S10 obtain large amounts of virtual water from other sectors, with the values of $137.54 \times 10^{9} \mathrm{~m}^{3}, 90.24 \times 10^{9} \mathrm{~m}^{3}$ and $41.88 \times 10^{9} \mathrm{~m}^{3}$, respectively.

Table 3. Inter-sector virtual water flow in China $\left(10^{9} \mathrm{~m}^{3}\right)$.

\begin{tabular}{|c|c|c|c|c|c|c|c|c|c|c|c|c|c|c|c|}
\hline & S1 & S2 & S3 & S4 & S5 & S6 & S7 & S8 & S9 & S10 & S11 & S12 & S13 & S14 & Sum \\
\hline S1 & 0 & 0.96 & 82.74 & 32.1 & 4.53 & 2.29 & 3.33 & 0.7 & 1.2 & 12.56 & 4.17 & 1.88 & 0.54 & 73.71 & 220.7 \\
\hline S2 & 0.18 & 0 & 0.23 & 0.29 & 0.06 & 0.06 & 0.27 & 0.09 & 0.17 & 1.06 & 0.31 & 0.05 & 0.10 & 2.43 & 5.29 \\
\hline S3 & 0.23 & 0.01 & 0 & 0.14 & 0.01 & 0.01 & 0.02 & 0.01 & 0.01 & 0.11 & 0.04 & 0.01 & 0.01 & 0.75 & 1.34 \\
\hline S4 & 0.03 & 0.01 & 0.04 & 0 & 0.03 & 0.03 & 0.04 & 0.01 & 0.02 & 0.15 & 0.06 & 0.03 & 0.01 & 0.53 & 0.99 \\
\hline S5 & 0 & 0 & 0 & 0 & 0 & 0 & 0 & 0 & 0 & 0.01 & 0.01 & 0 & 0 & 0.06 & 0.1 \\
\hline S6 & 0.14 & 0.04 & 0.48 & 0.34 & 0.06 & 0 & 0.09 & 0.07 & 0.08 & 0.83 & 0.20 & 0.05 & 0.03 & 3.49 & 5.89 \\
\hline S7 & 0.86 & 0.21 & 0.85 & 1.27 & 0.19 & 0.21 & 0 & 0.15 & 0.24 & 2.74 & 0.79 & 0.11 & 0.11 & 7.08 & 14.8 \\
\hline S8 & 0.1 & 0.05 & 0.16 & 0.15 & 0.04 & 0.03 & 0.06 & 0 & 0.11 & 0.86 & 0.23 & 0.03 & 0.02 & 3.3 & 5.14 \\
\hline S9 & 0.19 & 0.13 & 0.29 & 0.3 & 0.1 & 0.09 & 0.13 & 0.09 & 0 & 3.25 & 0.83 & 0.08 & 0.06 & 4.57 & 10.11 \\
\hline $\mathrm{S} 10$ & 0.01 & 0.01 & 0.01 & 0.02 & 0 & 0 & 0.01 & 0 & 0.01 & 0 & 0.04 & 0 & 0 & 0.2 & 0.31 \\
\hline S11 & 0.02 & 0.01 & 0.02 & 0.02 & 0.01 & 0.01 & 0.01 & 0.01 & 0.02 & 0.11 & 0 & 0 & 0.01 & 0.42 & 0.66 \\
\hline $\mathrm{S} 12$ & 0.02 & 0.01 & 0.04 & 0.05 & 0.01 & 0.06 & 0.02 & 0.02 & 0.04 & 0.25 & 0.06 & 0 & 0.01 & 0.46 & 1.04 \\
\hline $\mathrm{S} 13$ & 3.28 & 2.16 & 4.31 & 5.22 & 1.07 & 1.14 & 3.15 & 1.34 & 2.71 & 17.01 & 4.73 & 0.66 & 0 & 40.53 & 87.31 \\
\hline $\mathrm{S} 14$ & 0.67 & 0.24 & 1.06 & 1.15 & 0.19 & 0.19 & 0.37 & 0.18 & 0.29 & 2.94 & 0.91 & 0.12 & 0.14 & 0 & 8.44 \\
\hline Sum & 5.73 & 3.84 & 90.23 & 41.05 & 6.3 & 4.12 & 7.5 & 2.67 & 4.9 & 41.88 & 12.38 & 3.02 & 1.04 & 137.53 & \\
\hline
\end{tabular}

Based on Equation (12), the virtual water export considering internal linkage is calculated (Figure 12). It is greatly different from that without considering internal linkage. The sectors that mainly pull China's virtual water export are S1 and S13. The summation proportion of virtual water export from these two sectors is up to $81 \%$. There are two reasons for this virtual water structure: one is that products of the major sectors' virtual water export not considering internal linkage (S10, S4, S14) 
obtained raw material from these two sectors; the other is that the total water consumption coefficients of these two sectors are far greater than that of other sectors. The total water consumption coefficient of S1 in 2007 was $6913.4 .8 \mathrm{~m}^{3} / 10^{4} \$$, which is 6.9 and 3.87 times greater than that of California and Illinois, USA, in 2008 ([34]). Improving water use efficiency plays an important role in lowering virtual water export in China.

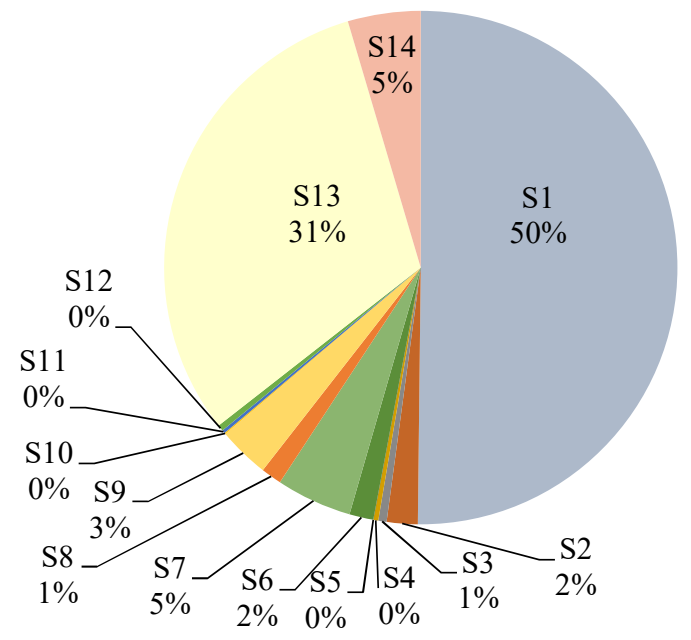

Figure 12. Virtual water export considering internal linkage.

\subsection{Embodied Carbon Emissions Flow Chain}

Table 4 shows the inter-sectoral flow of embodied carbon emissions. It shows that S9, S7, S8, S2 and S13 are major sources of carbon emissions for other sectors. The annual average carbon emissions flowing from S9 to S14, S10 and S11 is $638.7 \times 10^{6} \mathrm{t}, 418.52 \times 10^{6} \mathrm{t}$ and $132.72 \times 10^{6} \mathrm{t}$; the annual average carbon emissions flowing from S7 to S14, S10 and S4 is $540.64 \times 10^{6} \mathrm{t}, 184.18 \times 10^{6} \mathrm{t}$ and $82.46 \times 10^{6} \mathrm{t}$, respectively; the annual average carbon emissions flowing from sector S8 to sectors S14 and S10 is $448.23 \times 10^{6} \mathrm{t}, 98.02 \times 10^{6} \mathrm{t}$; and the annual average carbon emissions flowing from S2 to S14 and S10 is $253.93 \times 10^{6}$ t, $104.82 \times 10^{6}$ t. S14, S4 and S10, which export embodied carbon emissions, gain large amounts of carbon emissions from other sectors inside China.

Table 4. Inter-sector embodied carbon emissions flow in China $\left(10^{6} \mathrm{t}\right)$.

\begin{tabular}{|c|c|c|c|c|c|c|c|c|c|c|c|c|c|c|c|}
\hline & S1 & S2 & S3 & S4 & S5 & S6 & S7 & S8 & S9 & S10 & S11 & S12 & S13 & S14 & Sum \\
\hline S1 & 0 & 0.75 & 34.45 & 13.45 & 2.05 & 1.14 & 1.21 & 0.27 & 0.39 & 5.41 & 2.09 & 0.66 & 0.24 & 33.24 & 95.35 \\
\hline $\mathrm{S} 2$ & 15.26 & 0 & 21.6 & 27 & 5.87 & 6.63 & 22.68 & 8.02 & 13.49 & 104.82 & 34.66 & 4.31 & 10.18 & 253.93 & 528.47 \\
\hline S3 & 6.64 & 0.6 & 0 & 4.75 & 0.52 & 0.43 & 0.65 & 0.18 & 0.26 & 4.06 & 1.56 & 0.22 & 0.19 & 27.49 & 47.54 \\
\hline S5 & 0.26 & 0.38 & 0.46 & 0.49 & 0 & 0.3 & 0.17 & 0.1 & 0.19 & 1.9 & 1.06 & 0.11 & 0.07 & 9.37 & 14.86 \\
\hline S6 & 1.42 & 0.82 & 5.46 & 3.94 & 0.77 & 0 & 0.84 & 0.72 & 0.74 & 9.81 & 2.7 & 0.47 & 0.32 & 44.93 & 72.94 \\
\hline S7 & 47.4 & 22.84 & 58.14 & 82.46 & 14.41 & 17 & 0 & 9.08 & 12.29 & 184.18 & 64.57 & 6.44 & 7.65 & 540.64 & 1067.11 \\
\hline $\mathrm{S} 10$ & 1.08 & 1.5 & 1.66 & 2.05 & 0.43 & 0.51 & 0.77 & 0.44 & 0.66 & 0 & 6.15 & 0.25 & 0.67 & 29.75 & 45.9 \\
\hline S11 & 0.53 & 0.26 & 0.69 & 0.68 & 0.14 & 0.17 & 0.29 & 0.13 & 0.36 & 3.25 & 0 & 0.11 & 0.15 & 13.77 & 20.52 \\
\hline $\mathrm{S} 12$ & 1.86 & 1.98 & 4 & 4.61 & 1.24 & 4.87 & 1.39 & 1.27 & 2.92 & 24.47 & 6.87 & 0 & 0.63 & 50.48 & 106.59 \\
\hline $\mathrm{S} 13$ & 13.9 & 17.75 & 21.45 & 25.7 & 5.83 & 6.31 & 12.91 & 6.03 & 10.91 & 86.95 & 28.05 & 3.00 & 0 & 222.89 & 461.7 \\
\hline S14 & 10.47 & 8.76 & 21.79 & 22.03 & 4.25 & 4.47 & 5.26 & 2.77 & 4.48 & 63.71 & 24.09 & 1.96 & 3.15 & 0 & 177.19 \\
\hline Sum & 126.55 & 95.5 & 224.56 & 238.75 & 54.03 & 60.49 & 64.07 & 38.24 & 56.7 & 1011.28 & 338.26 & 29.2 & 34.08 & 2338.4 & \\
\hline
\end{tabular}

The embodied carbon emissions considering internal linkage are calculated according to Equation (13) and the results are shown in Figure 13. The sectors that mainly pull China's embodied carbon emissions export are S9, S7, S2, S13 and S8. The summation proportion of embodied carbon emissions export by these five sectors reaches $85 \%$. The export proportion of S4 drops from 36\% to $1 \%$ when considering the internal linkage among different sectors. The export proportion of the three heavy 
sectors of S2, S7 and S9 all play important roles in the two analytical approaches. The reasons for the characteristics of the embodied carbon emissions trade are: firstly, S4 and S10 need to obtain large amounts of energy resources from S9, S7, S8, S2 and S13, while S9, S7, S8 and S2 gain much energy from themselves; and secondly, the total carbon emission intensity of heavy industrial sectors in China is high compared to other sectors.

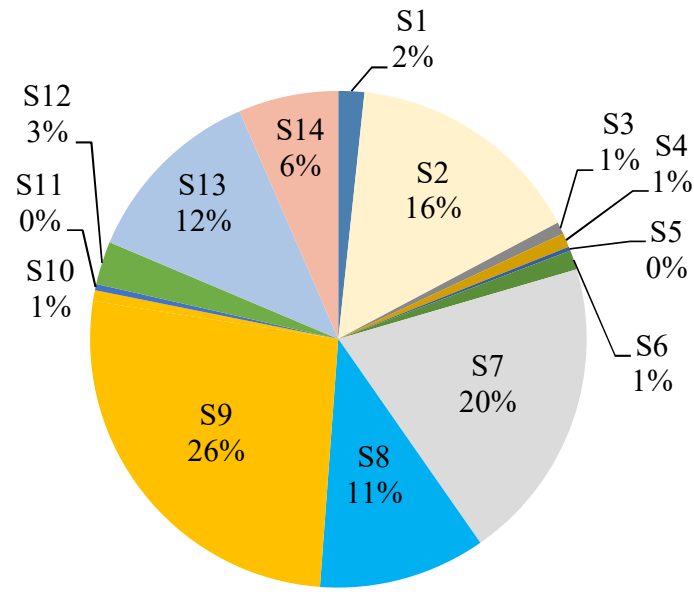

Figure 13. Embodied carbon emissions export considering internal linkage.

Carbon emission intensity $\left(\mathrm{CO}_{2}\right.$ emissions divided by gross domestic product (GDP)) is an important indicator to reflect regional carbon emission performance. Figure 14 depicts the change trend of the $\mathrm{CO}_{2}$ emission intensity in some countries. The GDP value of each country is calculated based on the market exchange rates (IEA 2017). As the figure shows, carbon emission intensity in developed countries such as the USA, Norway, Australia, Canada and Japan is below $0.5 \mathrm{~kg} / \$$, and carbon emission intensity in Japan, Norway and Brazil is less than $0.3 \mathrm{~kg} / \$$. Carbon emissions in developing countries such as China and India in 2015 are more than $1.5 \mathrm{~kg} / \$$. Although there was a drastic decline in carbon emission intensity in developing countries with technological developments during 1990-2015, a huge gap still exists between the developing and developed countries. The decline in carbon emission intensity kept the export of carbon emissions stable rather than increasing with a sharp increase in trade after 2002 in China. At the same export rate, the products from China embodied much more carbon emissions than other countries. It is important for China to reduce the carbon emission intensity, especially for such sectors as S2, S7, S8 and S9, which are the main sources of carbon emissions in both inter-sectoral linkage and external trade.

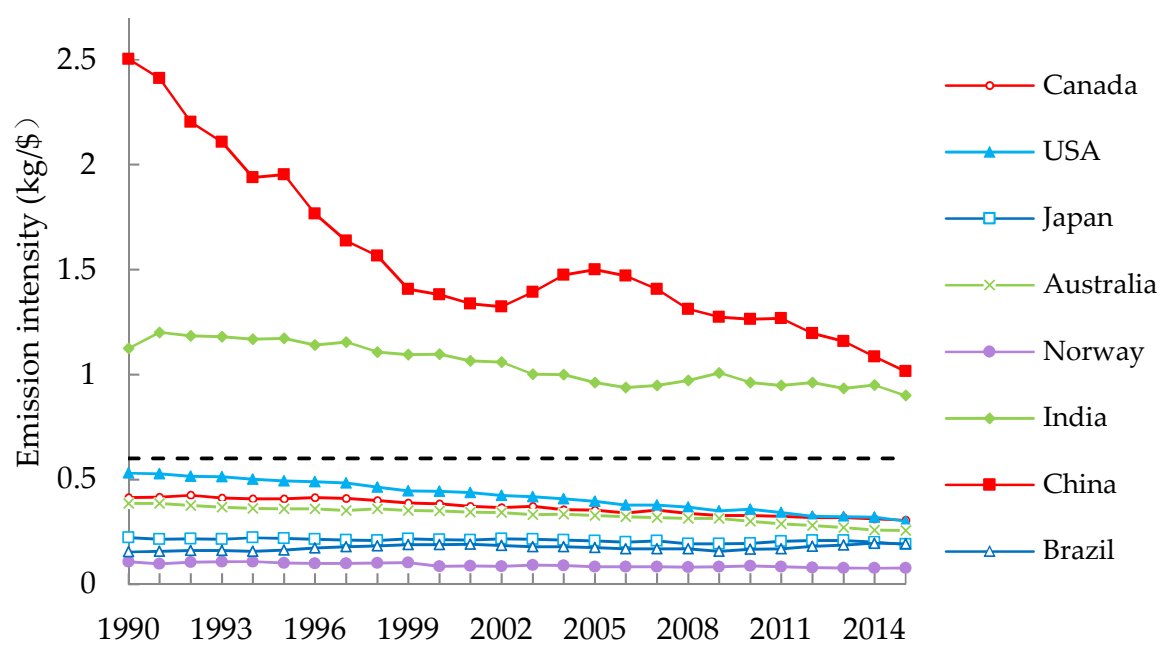

Figure 14. $\mathrm{CO}_{2}$ emission intensity, 1990-2015 (IEA). 


\subsection{Policy Implications}

China is a net exporter of virtual water and embodied carbon emissions; therefore, the government should pay more attention to the production than the consumption on the issue of resources conservation and carbon emissions reduction. To alleviate resource pressure and environmental problems, China has paid much attention to the sustainable use of water and $\mathrm{CO}_{2}$ emissions in the last 10 years. Overall, three reasons contribute to virtual water flows: water utilization efficiency, commodity trade structure and trade volume. It is basically impossible to control trade volume solely for environmental purposes, though it has dramatic effects on virtual water trade. It is more feasible to discuss policies for improving water utilization efficiency and adjusting export composition. Net virtual water exports mainly embodied in products of S4, S14 and S10 when not considering the flow of raw materials in the industrial chain; more than $80 \%$ of virtual water export is ultimately from S1 and S13 in the supply chain. S1 currently consumes about $68.16 \%$ of total water resources and has a much higher water coefficient compared with other sectors. The average national irrigation water use coefficient was 0.50 in 2012, which is far below those of developed countries or regions $(0.7-0.8)$. Therefore, to improve agricultural water use efficiency, efforts such as recycling irrigation and choosing suitable areas for agricultural production should be taken. Moreover, China must industrialize high-tech equipment to realize new types of industrialization, and adjust industrial structure instead of developing industrial sectors dependent on agricultural products. Additionally, optimizing the production structure is a vital approach to curb indirect water consumption; the export ratio of commodities with lower total water consumption coefficients should be expanded, especially for service industries. Last but not least, China should make full use of the water saving effect from importing water-intensive products to relieve water scarcity.

To achieve the country's energy consumption and emissions reduction commitments, China has launched plenty of energy conservation policies. Most of the policies place emphasis on typical heavy industries such as iron and steel, building materials, petrochemical, chemical, nonferrous metals and power industries. For instance, to target a $17 \%$ reduction in $\mathrm{CO}_{2}$ emissions per unit of GDP, China has closed many backward production facilities. In the meantime, environmental policies should not ignore the supply chain of the carbon emissions. For sectors with high total carbon emission intensity, raising the utilization and conservation efficiency of intermediate material input or reducing intermediate material input are valuable measures. Otherwise, the total industrial production and emissions from these sectors may still increase due to the high demand for their products though there are significant emission intensity reduction efforts. Thus, reducing the carbon emission intensity of different sectors is more significant than reducing or even closing the high carbon consumption sectors.

Overall, China has achieved the transformation of export commodity structure from primary product to industrial product. In the future, it should pay more attention to improving resource use efficiency, optimizing industrial structure and eliminating high resource and energy consuming industrial sectors to realize sustainable economic development.

However, this paper only considers $\mathrm{CO}_{2}$ emissions in the GHG and does not involve other GHG gases such as $\mathrm{CH}_{4}, \mathrm{NO}_{x}$, and $\mathrm{O}_{3}$ and so on. On the one hand, the national energy consumption data of every sector are published annually by National Bureau of Statistics of China; on the other hand, the classification of energy consumption data is consistent with that of the industrial sectors in the input-output table, which increases the reliability of the analysis. Inter-sectoral linkage and external trade analysis for other GHG gases in China can be further jobs for authors to launch in the future.

\section{Conclusions}

Water scarcity and carbon emissions are two important issues threating the sustainable and healthy development in China. The objectives of this study are to investigate the inter-sectoral linkage of water and energy resources among different sectors inside China and internal trade with other countries, and to identify the ultimate source of virtual water and carbon emissions and to grasp key sectors in the economic system applying input-output analysis. The main conclusions are as follows. 
As far as water resources are concerned, linkage analysis show that agriculture, and the electric and water industry have high independence because they output much but input little virtual water from other sectors. Sectors such as the paper and printing industry, the petrochemical industry, other nonmetallic mineral products industry, and the metal products industry output virtual water to other sectors and input virtual water meanwhile from other sectors. Sectors which have a high dependence on other sectors include the textile garment leather products industry, and the general machinery and equipment manufacturing industry, and the architecture and service industry. About $78 \%$ of virtual water consumption in the architecture and service industry is obtained from other sectors to meet the final demands. China was the net exporter of virtual water during 1997-2015, which aggravated its water scarcity. The annual average net export was $13.72 \times 10^{9} \mathrm{~m}^{3}$, with the largest value of $36.58 \times 10^{9} \mathrm{~m}^{3}$ in 2007 . From the perspective of the industrial chain, the virtual water export from agriculture, and the electric and water industry account for more than $80 \%$ of China's output. It indicates that the ultimate source of virtual water in China's output are from these two sectors. The water use coefficient of agriculture, and the electric and water industry are much higher than those of other sectors in China. The water use coefficients of all sectors in China are greater than those of other developed countries. It is extremely urgent for China to lower its total water consumption coefficient, especially for agriculture, and the electric and water industry to relieve water resource stress.

As far as embodied carbon emissions are concerned, for heavy industries including the metal products industry, the petrochemical industry, other nonmetallic mineral products industry, the electric and water industry, and the mining industry, approximately $50 \%$ of their energy consumed come from the internal exchange and $90 \%$ of their energy consumption is transferred into other sectors. Sectors including the food beverage and tobacco products industry, the architecture and service industry, the general machinery and equipment manufacturing industry, the transportation equipment manufacturing industry, and the textile garment leather products industry output more carbon emissions than they obtain from other sectors. China's net exports of embodied carbon emissions reached $2.0 \times 10^{8} \mathrm{t}$, which may further deteriorate its environment. Manufacturing industries play an important role in China's international embodied carbon emissions trade. From the perspective of the industrial chain, heavy industrial sectors including the metal products industry, the petrochemical industry, other nonmetallic mineral products industry, and the mining industry are the ultimate energy source for both internal linkage and external trade of carbon emissions. China's carbon emission intensity is not only higher than that of developed countries or regions such as the USA, Japan, and Canada and so on, but also is higher than that of developing countries such as India and Brazil. Therefore, more efforts should be implemented to reduce carbon emission intensity.

Author Contributions: H.H. conceived, designed and revised the manuscript; Y.H. revised the manuscript and supervised the whole process; X.L. revised the manuscript; L.C. revised the manuscript and supervised the whole process; D.J. designed the methodology modification. J.Z. and C.W. polish the language. All authors read and approved the final manuscript.

Funding: This research received no external funding.

Acknowledgments: This study was supported by the National Natural Science Foundation of China (Grants Nos. 51709107; 51679089; 51609082); and the National Key Research and Development Program of China (Grant No. 2016YFC0401402).

Conflicts of Interest: The authors declare no conflict of interest.

\section{References}

1. Ercin, A.E.; Hoekstra, A.Y. Carbon and Water Footprints Concepts, Methodologies and Policy Responses; United Nations World Water Assessment Programme; UNESCO: London, UK, 2012.

2. FAO (Food and Agriculture Organization of the United Nations). Climate Change, Water and Food Security; FAO: Rome, Italy, 2011.

3. Soytas, U.; Sari, R.; Ewing, B.T. Energy consumption, income, and carbon emissions in the United States. Ecol. Econ. 2007, 62, 482-489. [CrossRef] 
4. Herrmann, I.T.; Hauschild, M.Z. Effects of globalization on carbon footprints of products. CIRP Ann.-Manuf. Technol. 2009, 58, 6-13. [CrossRef]

5. Allan, J.A. Virtual water-The water, food, and trade nexus: Useful concept or misleading metaphor? Water Int. 2003, 28, 106-113. [CrossRef]

6. Zeitoun, M.; Allan, J.A.; Mohieldeen, Y. Virtual water "flows" of the Nile Basin, 1998-2004: A first approximation and implications for water security. Glob. Environ. Chang. 2010, 20, 229-242. [CrossRef]

7. Chouchane, H.; Krol, M.S.; Hoekstra, A.Y. Virtual water trade patterns in relation to environmental and socioeconomic factors: A case study for Tunisia. Sci. Total Environ. 2018, 613-614, 287-297. [CrossRef] [PubMed]

8. Wahba, S.M.; Scott, K.; Steinberger, J.K. Analyzing Egypt's water footprint based on trade balance and expenditure inequality. J. Clean. Prod. 2018, 198, 1526-1535. [CrossRef]

9. Brindha, K. International virtual water flows from agricultural and livestock products of India. J. Clean. Prod. 2017, 161, 922-930. [CrossRef]

10. Novo, P.; Garrido, A.; Varela-Ortega, C. Are virtual water "flows" in Spanish grain trade consistent with relative water scarcity? Ecol. Econ. 2009, 68, 1454-1464. [CrossRef]

11. Antonelli, M.; Tamea, S.; Yang, H. Intra-EU agricultural trade, virtual water flows and policy implications. Sci. Total Environ. 2017, 587-588, 439-448. [CrossRef] [PubMed]

12. Zhong, Z.Q.; Jiang, L.; Zhou, P. Transnational transfer of carbon emissions embodied in trade: Characteristics and determinants from a spatial perspective. Energy 2018, 147, 858-875. [CrossRef]

13. Peters, G.P.; Minx, J.C.; Weber, C.L.; Edenhofer, O. Growth in emission transfers via international trade from 1990 to 2008. Proc. Natl. Acad. Sci. USA 2011, 108, 8903-8908. [CrossRef] [PubMed]

14. Davis, S.J.; Caldeira, K. Consumption-based accounting of $\mathrm{CO}_{2}$ emissions. Proc. Natl. Acad. Sci. USA 2010, 107, 5687-5692. [CrossRef] [PubMed]

15. Jiang, X.M.; Guan, D.B. The global $\mathrm{CO}_{2}$ emissions growth after international crisis and the role of international trade. Energy Policy 2017, 109, 734-746. [CrossRef]

16. Andrew, R.M.; Davis, S.J.; Peters, G.P. Climate policy and dependence on traded carbon. Environ. Res. Lett. 2013, 8, 034011. [CrossRef]

17. Antimiani, A.; Costantini, V.; Martini, C.; Salvatici, L.; Tommasino, M.C.; Chiara, M.; Salvatici, L.; Tommasino, M.C. Assessing alternative solutions to carbon leakage. Energy Econ. 2013, 36, $299-311$. [CrossRef]

18. Eichner, T.; Pethig, R. Unilateral consumption-based carbon taxes and negative leakage. Resour. Energy Econ. 2015, 40, 127-142. [CrossRef]

19. Böhringer, C.; Bye, B.; Fæhnb, T.; Rosendahl, K.E. Targeted carbon tariffs: Export response, leakage and welfare. Resour. Energy Econ. 2017, 50, 51-73. [CrossRef]

20. Chen, W.M.; Wu, S.M.; Lei, Y.L.; Li, S.T. Virtual water export and import in China's foreign trade: A quantification using input-output tables of China from 2000 to 2012. Resour. Conserv. Recycl. 2017. [CrossRef]

21. Tian, X.; Sarkis, J.; Genga, Y.; Qian, Y.Y.; Gao, C.X.; Bleischwitz, R.; Xu, Y. Evolution of China's water footprint and virtual water trade: A global trade assessment. Environ. Int. 2018, 121, 178-188. [CrossRef] [PubMed]

22. Wang, Y.B.; Liu, D.; Cao, X.C.; Yang, Z.Y.; Song, J.F.; Chen, D.Y.; Sun, S.K. Agricultural water rights trading and virtual water export compensation coupling model: A case study of an irrigation district in China. Agric. Water Manag. 2017, 180, 99-106. [CrossRef]

23. Cai, B.M.; Wang, C.C.; Zhang, B. Worse than imagined: Unidentified virtual water flows in China. J. Environ. Manag. 2017, 196, 681-691. [CrossRef] [PubMed]

24. Yan, Y.F.; Yang, L.K. China's foreign trade and climate change: A case study of $\mathrm{CO}_{2}$ emissions. Energy Policy 2010, 38, 350-356.

25. Andersson, F.N.G. International trade and carbon emissions: The role of Chinese institutional and policy reforms. J. Environ. Manag. 2018, 205, 29-39. [CrossRef] [PubMed]

26. Yuan, R.; Zhao, T. A combined input-output and sensitivity analysis of $\mathrm{CO}_{2}$ emissions in the high energy-consuming industries: A case study of China. Atmos. Pollut. Res. 2016, 7, 315-325. [CrossRef]

27. Duarte, R.; Sanchez, C.J.; Bielsa, J. Water use in the Spanish economy: An input-output approach. Ecol. Econ. 2002, 43, 71-85. [CrossRef] 
28. Wen, W.; Wang, Q. Identification of key sectors and key provinces at the view of $\mathrm{CO}_{2}$ reduction and economic growth in China: Linkage analyses based on the MRIO model. Ecol. Indic. 2019, 96, 1-15. [CrossRef]

29. Fang, D.L.; Chen, B. Linkage analysis for water-carbon nexus in China. Appl. Energy 2018, 225, $682-695$. [CrossRef]

30. Fang, D.L.; Chen, B. Linkage analysis for the water-energy nexus of city. Appl. Energy 2017, 189, 770-779. [CrossRef]

31. Yang, X.C.; Wang, Y.T.; Sun, M.X.; Wang, R.Q.; Zheng, P.M. Exploring the environmental pressures in urban sectors: An energy-water-carbon nexus perspective. Appl. Energy 2018, 228, 2298-2307. [CrossRef]

32. Velázquez, E. An input-output model of water consumption: Analyzing intersectoral water relationships in Andalusia. Ecol. Econ. 2006, 56, 226-240. [CrossRef]

33. Deng, G.Y.; Wang, L.; Xu, X.Y. Linkage effect of virtual water trade in China's industrial products-based on generalized hypothetical extraction method. Ecol. Indic. 2018, 93, 1302-1320. [CrossRef]

34. Mubako, S.; Lahiri, S.; Lant, C. Input-output analysis of virtual water transfers: Case study of California and Illinois. Ecol. Econ. 2013, 93, 230-238. [CrossRef]

35. Sánchez, C.J.; Duarte, R. Analyzing Pollution by way of vertically integrated coefficients with an application to the water sector in Aragon. Camb. J. Econ. 2003, 27, 433-488. [CrossRef]

(c) 2018 by the authors. Licensee MDPI, Basel, Switzerland. This article is an open access article distributed under the terms and conditions of the Creative Commons Attribution (CC BY) license (http://creativecommons.org/licenses/by/4.0/). 